\title{
Film dan Perempuan: Kegagalan Film Gone Girl Dalam Membentuk Sosok Perempuan Baru di Industri Film Hollywood
}

\author{
Amida Yusriana, Rahmawati Zulfiningrum \\ (amidayusriana88@gmail.com) \\ (Universitas Dian Nuswantoro)
}

\begin{abstract}
Gone Girl is a film produced in 2014 and is an adaptation of a best-selling novel by Gillian Flynn. Gone Girl can be divided into three parts. The interesting point in this movie is the gender focus of Gillian Flynn's way in depicting Amy. According to her, this is an attempt to show that woman can have a criminal mind as a man. However, the depiction of woman in patriarch charasteristic is still can be found in the movie. This research is to find out how the movie Gone Girl failed to create a new woman character.This study uses the postmodernism theory to explain. Result of this study indicates that the figure of Amy Dunne is described as a heroine with typical utopia and as a villain Amy can not be separated from the feminines roles of patriarch. Among others: weak, emotional human being, depending and using her body as a weapon.
\end{abstract}

Keywords: Gone Girl, Postmodernisme, Villain

\section{Pendahuluan}

Gone Girl adalah sebuah film kategori thriller psikologis yang disutradarai oleh David Fincher yang merupakan adaptasi dari novel best seller dengan judul sama karya Gillian Flynn. Novel Gone Girl telah terlebih dahulu terbit sejak tahun 2012 dan masuk ke dalam daftar The New York Times Best Seller. Kesuksesan tersebut yang kemudian membuat Gone Girl akhirnya diangkat ke layar lebar pada tahun 2014 lalu. Film dengan durasi 149 menit tersebut berhasil menjadi Box Office dengan meraup keuntungan senilai \$369.330.363 di seluruh dunia dan memperoleh peringkat ke 13 dalam daftar film Box Office (http://www.boxofficemojo.com/movies /?id=gonegirl.htm diakses tanggal 04 November 2015 pukul 13.47).

Gone Girl memperoleh banyak kritik yang baik dengan website ternama Rotten Tomatoes memberikan penilaian rating $88 \%$ secara keseluruhan. Film ini juga memperoleh banyak pujian karena kehebatan para aktor dan aktris utama film tersebut. Rosamund Pike sebagai pemeran utama perempuan menunjukkan peran yang sangat baik dalam menggambarkan tokoh Amy Dunne dalam novel Gone Girl. Selain itu didukung oleh peran aktor utama, Ben Affleck (http://www.hollywoodreporter.com/ne ws/box-office-david-finchers-gone738181 diakses tanggal 04 November 2015 pukul 14.05). Gone Girl juga masuk ke dalam daftar 10 tertinggi pada kritik film dunia:

Gambar 1

Daftar Peringkat Gone Girl Pada Kritik Film
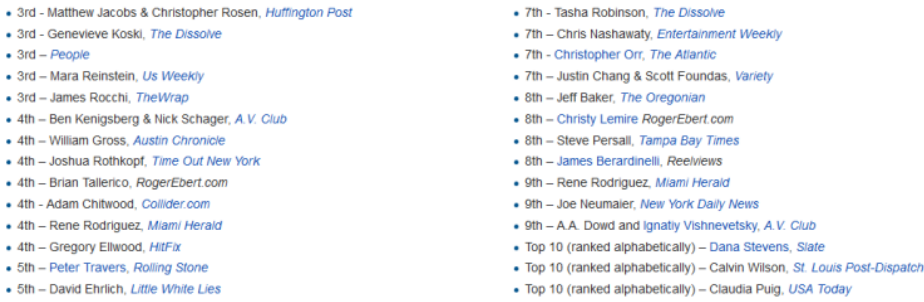

Sumber:

http://www.metacritic.com/feature/filmcritic-top-10-lists-best-movies-of-2014 diakses tanggal 05 November 2015 pukul 13.18 WIB

Gone Girl memperoleh penerimaan yang baik dari masyarakat 
karena menawarkan cerita yang cukup berbeda dibandingkan banyak film

lainnya. Berkisah tentang sebuah rumah tangga yang mengalami konflik. Pernikahan antara Nick Dunne dan Amy Dunne. Film berjalan dengan menggunakan waktu dan perhitungan hari sebagai pijakan penonton. Diawali dengan hari ulang tahun pernikahan kelima mereka, Nick kembali ke rumah dan mendapati bahwa istrinya tidak lagi berada di rumah. Hilangnya Amy Dunne menarik perhatian masyarakat karena Amy adalah inspirasi dari tokoh buku anak - anak Amazing Amy karya orangtua Amy.

Kemudian cerita berkisar aksi pencarian detektif Rhonda Boney dalam mencari bukti keberadaan Amy. Dengan banyaknya bukti di rumah tempat terjadinya kejahatan, penyelidikan semakin mengarahkan pada Nick Dunne sang suami sebagai tersangka dalam kasus tersebut. Setelah melakukan penyelidikan forensik, ditemukan banyak darah di dapur rumah tersebut dan membawa ke kesimpulan baru bahwa Amy Dunne telah dibunuh.

Sejak menit awal film dimulai, penonton dapat mencium ketidakberesan dari rumah tangga Nick dan Amy. Kisah penceritaan dibuat alur maju dan mundur, sehingga penonton dapat menyimpulkan sendiri bagaiamana sebenarnya kondisi rumah tangga pernikahan tersebut. Nick Dunne dibantu dengan saudara kembarnya berusaha mencari tahu mengapa Amy Dunne menghilang dan sekaligus menghindari incaran media yang mulai menyalahkan Nick sebagai tersangka utama.

Di sisi lain, kemudian film menunjukkan bahwa Amy Dunne ternyata telah memalsukan kematiannya. Sebaliknya ia adalah otak kejahatan tersebut dan menjadi si penjahat dalam film Gone Girl. Seluruh aksi kejahatan yang terjadi di rumah tersebut ternyata adalah rencana Amy untuk membalas dendam akan sikap dan perselingkuhan sang suami. Amy tidak puas dengan pernikahannya terutama karena kepindahan mereka dari New York ke kota kecil di Missouri.

Karena terus dipojokkan oleh pihak media sebagai suami yang jahat, Nick menghubungi pengacara, Tanner Bolt. Tanner Bolt adalah pengacara spesialis dibidang membela pria yang dituduh membunuh istrinya. Selama upaya pencarian bahan bukti tersebut, Nick bertemu dengan mantan pacar Amy, Tommy O'Hara yang selama ini dituduh sebagai pemerkosa dan Desi Collings yang pernah dilaporkan Amy sebelumnya.

Dalam pelariannya dan rencananya membuat perangkap untuk Nick, Amy diserang oleh teman yang ia temui di tempat pelariannya dan mereka mencuri uang yang dibawa oleh Amy. Karena tidak memiliki uang lagi, Amypun mengubah rencananya. Ia kemudian menemui Desi Collings dan meminta disembunyikan di rumah musim panas milik Desi. Amy meyakinkan pada Desi bahwa ia lari dari Nick karena takut. Desi setuju untuk menyembunyikannya di rumah musim panas yang dilengkapi banyak kamera.

Di sisi lain, Nick meyakinkan saudaranya bahwa ia tidak bersalah. Bersama Tanner Bolt, mereka berencana menarik perhatian publik dengan hadir dalam acara talk show. Dalam talk show tersebut, Nick meyakinkan bahwa ia tidak bersalah dan meminta maaf kepada Amy melalui layar televisi.

Ternyata upaya tersebut berhasil meyakinkan Amy. Kemudian Amy mengubah rencananya kembali dan memanipulasi situasi sehingga seolah olah Desi yang telah menculiknya dan 
melakukan kekerasan seksual kepadanya. Amy melarikan diri dari rumah musim panas Desi dengan menggorok leher Desi saat mereka akan melakukan berhubungan intim.

Selesai melakukan aksinya, Amy kembali ke rumahnya dengan baju berlumuran darah dan melakukan kesaksian palsu di depan polisi. Kasus dianggap selesai dengan kembalinya Amy ke rumah. Meskipun demikian, mengetahui niat awal Nick, ia terus curiga pada Amy. Kemudian keduanya berusaha menunjukkan ke publik kehidupan pernikahan setelah kejadian tersebut. Karena takut dengan Amy, Nick berusaha meninggalkan Amy. Namun Amy berhasil menahan niat tersebut dengan menggunakan contoh sperma milik Nick untuk membuatnya hamil. Film diakhiri dengan upaya keduanya menunjukkan kepada publik melalui sebuah talk show bahwa mereka akan memiliki anak segera.

Yang menarik dalam film ini adalah tokoh antagonisnya adalah seorang perempuan. Banyak film mainstream yang menjadikan pria sebagai tokoh antagonis pada film dengan jenis kriminal. Di antara 50 tokoh antagonis dalam film jenis apa saja, hanya terdapat 6 perempuan sebagai tokoh antagonis dan satu di antaranya adalah tokoh dengan kekuatan supranatural (http://www.ranker.com/list/scariestpsychological-thrillers-of-alltime/ranker-film diunduh tanggal 05 November 2015 Pukul 9.14).

Sedikitnya jumlah perempuan yang digambarkan sebagai tokoh antagonis khususnya dalam film berjenis thriller psikologis membuat film Gone Girl terasa berbeda. Dalam Gone Girl, sebagai antagonis, Amy Dunne digambarkan sebagai perempuan yang hampir sempurna. Seorang perempuan dewasa kaukasian yang cantik, berambut pirang, bertubuh ideal, manipulatif dan cerdas. Ia juga terkenal karena merupakan inspirasi dari tokoh buku cerita anak - anak Amazing Amy. Penggambaran tentang tokoh Amy ini diperkuat dengan pemberian narasi si tokoh dalam menggambarkan runtutan rencana kejahatannya. Tokoh Amy dengan detil menggambarkan bagaimana cara menjebak suaminya sebagai tersangka pembunuhan Amy. Dengan memperhitungkan segalanya, seperti membentuk alibi, saksi, menentukan bukti - bukti, kejahatan Amy hanya dapat dilakukan oleh seorang perempuan cerdas.

Pada penelitian yang dilakukan pada tahun 1969 - 1983 hampir 56\% dari acara prime time menggambarkan kekerasan dan perempuan digambarkan tiga kali lebih banyak jumlahnya dibanding pria sebagai korban kekerasan tersebut (Richmond-Abbott, 1992: 98 - 99).

Perempuan sebagai pelaku bukan sebagai korban kekerasan menjadi hal yang sangat jarang dalam media mainstream, itulah mengapa tokoh Amy sekilas terasa istimewa. Terutama penggambaran tokoh Amy di awal film. Untuk memudahkan, film Gone Girl dapat dibagi menjadi tiga bagian:

1. Fokus Nick: Investigasi pencarian Amy Dunne

2. Fokus Amy: Narasi penceritaan kejahatan Amy

3. Amy mengubah rencana karena uangnya telah dicuri

Tokoh Amy yang telah terbentuk sebagai penjahat sempurna di bagian kedua ternyata harus jatuh kembali dalam gambaran lama seorang perempuan: obyek seksual, emotional dan bergantung pada pria (dependent). Walaupun kata 'obyek' kurang tepat digunakan karena Amy menggunakan daya tarik seksualnya sebagai sebuah senjata. Namun, kembali film ini 
menggambarkan perempuan sebagai mahluk seksual dan tidak dapat terlepas dari pemanfaatan kekuatan seksual sekalipun untuk berbuat kejahatan. Selain itu gambaran akhir saat Amy memutuskan untuk kembali kepada suaminya karena pernyataan suaminya di talk show, menunjukkan Amy sebagai manusia yang didorong oleh emosinya dan pemanfaatan Desi Collings menunjukkan bahwa Amy masih bergantung pada pria.

Film ini merupakan film yang mendapat sorotan kajian gender. Pada awalnya pengarang buku dan juga penulis script film Gone Girl, Gillian Flynn memang ingin menghindari penggambaran klise perempuan sebagai korban yang selalu ada dalam film film kriminal. Gillian ingin membuktikan bahwa perempuan memiliki pikiran jahat sama dengan pria. Bagi masyarakat, perempuan yang demikian masih menjadi hal yang mengejutkan karena perempuan selalu dianggap baik secara alamiah (http://www.timeout.com/chicago/book s/gillian-flynn-on-gone-girl-interview diakses tanggal 05 November 2015 Pukul 13.12WIB).

Dalam wawancara lainnya yang dilakukan New York Times kepada Gillian, bahwa produser film yakni aktris Hollywood Reese Witherspoon ingin membuat film yang mampu membangun peran perempuan yang lebih baik, kemudian apakah Gone Girl menunjukkan kekuatan perempuan atau justru hanya mengembalikan stereotipe ke perempuan. Menanggapi pertanyaan tersebut, Gillian kembali menegaskan bahwa ia membuat tokoh Amy Dunne dengan harapan untuk menunjukkan bahwa perempuan tidak selalu baik secara alamiah seperti yang dituduhkan masyarakat selama ini (http://www.nytimes.com/2014/11/23/ar ts/talking-with-the-authors-of-gone-girl- and-wild.html?smid=fb-

nytimes\&smtyp $=$ cur\&bicmp $=$ AD\&bic mlukp=WT.mc_id\&bicmst $=140923272$ 2000\&bicmet $=1419773522000 \& \_r=1$ diakses tanggal 05 November 2015 pukul 13.28 WIB).

Dari pernyataan tersebut menunjukkan bahwa film Gone Girl merupakan film yang memang sejak awal memiliki kaitan dengan isu gender. Namun berdasarkan jawaban dari Gillian Flynn pada New York Times menguatkan bahwa Gillian tidak menyadari Gone Girl belum terlalu kuat dalam memberikan gambaran yang berbeda tentang perempuan karena dalam Gone Girl, Amy Dunne digambarkan memanfaatkan daya tarik seksualnya untuk memenangkan rencana kejahatannya pada bagian ketiga film. Penelitian ini disusun untuk mengetahui bagaimana film Gone Girl gagal menciptakan penggambaran perempuan dengan kekuatan yang baru?

\section{Penggambaran Perempuan di Media}

Dapat dikatakan bahwa perempuan dan media memiliki hubungan yang baik. Sayangnya hubungan baik itu tidak bersifat saling menguntungkan. Media lebih banyak memanfaatkan perempuan untuk kepentingannya. Perempuan telah lama digambarkan kurang manusiawi dalam media. Seringkali perempuan digambarkan sebagai mahluk seksual, yang keberadaannya selalu disangkut pautkan dengan eksplorasi seksual bagian - bagian tubuhnya. Dalam iklan misalnya, sebagai seorang konsumen, perempuan selalu diterpa iklan - iklan produk yang mengajak mereka menjadi lebih menarik lagi dan lagi.

Pesan implisit dalam iklan untuk perempuan adalah bahwa perempuan yang berpenampilan alami tidaklah cukup baik dan diharapkan dapat 
menggunakan produk - produk tertentu untuk meningkatkan penampilan. Ada juga pesan - pesan yang menekankan bahwa perempuan harus tetap muda dan melawan tanda - tanda penuaan. Pesan implisitnya adalah jika perempuan memang menua, itu akan jadi salahnya karena tidak mencoba sekuat tenaga untuk menghentikan waktu, karena sebagai perempuan tua, ia akan jadi tidak diperhatikan dan tidak berharga (Richmond-Abbott, 1992: 102).

Perempuan sebagai endorser pada sebuah iklan di media sering digambarkan tidak adil. Misalnya digambarkan seperti anak kecil, penonton pasif, bodoh atau tidak paham dan tidak kompeten. Hal ini yang menyebabkan sangat sulit bagi pria kemudian menganggap perempuan sebagai lawan bicara yang serius. Dalam kondisi lain, perempuan seringkali digambarkan dipegang, dilempar dan diperlakukan seperti obyek anak - anak untuk dimainkan oleh pria dewasa.

Hal lain yang perlu memperoleh perhatian khusus adalah kemenarikan seksual dalam iklan. Perempuan sering digambarkan telanjang. Seringkali pesan implisit yang dimunculkan adalah perempuan merupakan reward bagi pria jika ia menggunakan produk tersebut. Bahkan seringkali perempuan digambarkan sebagai obyek seksual pada iklan yang tidak ada hubungannya sama sekali (Richmond Abbott, 1992:103).

Dalam media yang lain, perempuan tidak jauh berbeda penggambarannya. Perempuan seringkali digambarkan sebagai pihak yang tidak berdaya dalam buku cerita maupun film. Penggambaran perempuan sebagai yang tidak berdaya hanya melanjutkan mainstream tulisan selama ini yang telah ada. Misal dalam komik Tarzan (April 1987), Robin
Wright menemukan 176 gambar pria dan 28 gambar perempuan (jumlah gambar monyet lebih banyak dibanding gambar perempuan). Pria berbicara 108 kali dibanding perempuan yang hanya 15 kali. Wright juga mencatat bahwa selama penceritaan, tokoh Jane digambarkan bersandar pada sesuatu misal batu, pohon, Tarzan dan biasanya digambarkan kusut, lelah dan ketakutan. Jane digambarkan bergantung pada pria, ia diculik, diselamatkan, ditenangkan, dipegangi, diancam dan diselamatkan kembali. Jane melakukan hal - hal yang lebih pasif seperti melihat, menunggu, istirahat dan bersembunyi. Ia berteriak saat ketakutan dan menangis karena ketakutan dan kesakitan. Sedangkan Tarzan berbicara paling sedikit tiga bahasa (Bahasa Inggris, Bahasa Yunani dan Bahasa Monyet), memperdaya, berkelahi dan membunuh baik pria maupun hewan serta menyelamatkan Jane tanpa terluka dan terobek bajunya (Kramarae, 1981: 85).

Dalam penggambaran lain di komik Wonder Woman (April 1978), sang heroine (pahlawan perempuan) tinggal di lingkungan yang didominasi oleh perempuan. Meskipun demikian, tidak ada pria tinggal di pulaunya. Meskipun demikian, ratu pulau tersebut memperoleh nasihat, kebijakan dan pengetahuan dari dua pria yang berasal dari dunia lain. Dari kedua contoh tersebut maka mainstream penggambaran perempuan adalah sebagai yang inferior dibanding pria. Saat menjadi heroine-pun tidak di antara pria dan alpha-nya tetap bergantung pada pria.

Berdasarkan telaah penelitian yang telah banyak dilakukan sebelumnya, menunjukkan bahwa media dan perempuan berbagi simbiosis parasitisme. Media cenderung merugikan perempuan, membingkai perempuan dengan bungkus yang salah. 
Buruknya, perempuan tidak berdaya menghadapi semua perilaku media terhadapnya. Selalu digambarkan sebagai manusia kelas kedua, membuat banyak perempuan sendiri tidak sadar bahwa ia tidak diperlakukan adil. Perempuan tidak menyadari bahwa ia tidak terartikulasi dengan baik. Media jarang menggambarkan perempuan yang cerdas dan sukses, perempuan yang baik, murni, tidak berdosa, lemah dan mencintai pasangannya dengan sepenuh hati jauh disukai oleh masyarakat secara umum.

Film Gone Girl kemudian berusaha menawarkan sesuatu yang berbeda. Tidak dengan menjadikan perempuan sebagai pahlawan, justru menjadikannya sebagai 'si jahat' dalam film kriminal. Keinginan Gillian Flynn adalah memberikan pencerahan kepada masyarakat bahwa perempuan bisa sama jahatnya dengan pria. Amy Dunne memiliki penggambaran yang luar biasa, cerdas dan manipulatif. Namun demikian, dalam penelitian ini masih ditemukan bahwa Gillian Flynn kembali jatuh ke penggambaran - penggambaran lama tentang perempuan yang biasa muncul di media.

\section{Teori Postmodernisme}

Hal yang menarik dalam buku ini adalah Gillian Flynn adalah seorang perempuan. Meski Gillian Flynn seorang perempuan, ia berusaha melepaskan perempuan dari belenggu penggambaran patriarki. Namun sayang sekali, Gillian Flynn adalah penulis perempuan yang belum berhasil lepas sepenuhnya dari belenggu patriarki sehingga ia tidak mampu meraih cita citanya menggambarkan sosok Amy Dunne yang sama sekali berbeda dari penggambaran media mainstream lainnya. Kondisi Gillian Flynn sebagai seorang perempuan inilah yang kemudian dapat digunakan untuk menjelaskan kenapa ia masih terjebak dalam penggambaran yang lama.

Teori postmodernisme dapat digunakan untuk menjelaskan situasi ini. Teori postmodernisme adalah teori yang memiliki hubungan 'sulit' dengan feminisme. Teori ini beranggapan bahwa tidak ada perempuan yang dapat lepas dari pikiran yang dibentuk dunia patriarki. Karena dunia yang dipahami perempuan dan pemahaman yang digunakan untuk memahami dunia dilihat dari sudut pandang patriarki. Pandangan terhadap dunia, memahami dunia adalah bagian dari yang dikenal dengan tatanan simbolik.

Teori ini didasarkan oleh teori Jacques Lacan. Menurut Lacan, terdapat tiga tahapan yang akan dilalui seorang bayi untuk tunduk ke tatanan simbolik yang adalah patriarki. Pada tahap pertama, fase pra-Oedipal, seorang bayi sama sekali tidak menyadari batasan egonya. Pada saat ini bayi belum menyadari perbedaan antara tubuhnya dan tubuh sang ibu.

Dalam fase kedua, fase cermin, dimana bayi berpikir bahwa citra dirinya, seperti terefleksi seperti cermin pandangan ibunya, adalah dirinya yang sesungguhnya. Menurut Lacan, ini adalah fase normal dalam perkembangan diri. Sang bayi harus pertama - tama melihat dirinya sebagaimana ibunya melihat dirinya, yaitu sebagai Liyan- sebelum sang bayi dapat melihat dirinya sendiri. Lacan mengklaim bahwa proses penemuan diri infantil berfungsi sebagai paradigma dari semua hubungan selanjutnya. Diri selalu menemukan dirinya melalui refleksi dirinya pada yang lain.

Fase ketiga, Fase Oedipal, termasuk periode ketika keterasingan antara ibu dan sang bayi menuju kedewasaan. Tidak seperti saat bayi, anak tidak melihat dirinya sebagai satu kesatuan; sebaliknya, anak melihat 
ibunya sebagai Liyan- seseorang tempatnya mengkomunikasikan keinginan - keinginannya dan karena itu, seseorang yang karena keterbatasan bahasa tidak dapat sungguh - sungguh memenuhi keinginan itu. Selama fase oedipal saja, hubungan ibu-anak yang sudah melemah lebih diperlemah lagi dengan intervensi sang ayah. Karena takut katrasi simbolik (kehilangan penanda falik untuk semua hal yang menyenangkan), sang anak memisahkan dirinya dari ibunya untuk memperoleh suatu medium (language) sebagai alat bagi sang anak untuk mempertahankan hubungannya dengan ibunya.

Pengalaman anak laki - laki dalam proses pemisahan dengan ibunya berlangsung secara berbeda dengan pengalaman anak perempuan. Dalam fase oedipal, anak laki - laki menolak identifikasi dengan ibunya, menghindari keadaan yang hening dan serupa dengan rahim, serta mendekatkan diri dengan ayah yang mempunyai anatomi yang lebih mirip. Anak laki - laki kemudian memasuki fase dirinya sebagai subyek dan individu, juga menginternalisasi tatanan dominan, peran penuh makna dalam masyarakat.

Anak perempuan tidak dapat sepenuhnya mengidentifikasi dirinya dengan ayahnya. Hasilnya, anak perempuan tidak dapat sepenuhnya menerima dan menginternalisasi tatanan simbolik (Tong, 1998: 288 - 289).

Inti dari teori postmodernisme dari Lacan adalah bahwa perempuan tertinggal dalam fase cermin. Pria mampu berpindah dari kerangka pemikiran yang merupakan hasil reflektif pemikiran ibunya menuju ke pemikirannya sendiri sebagai manusia laki - laki yang diakui oleh dunia. Dengan tatanan simbolik yang membela dirinya, maka dengan mudah pria memiliki pikirannya sendiri dalam fase oedipal. Sedangkan perempuan, dalam fase cermin memperoleh kerangka pemikiran dari ibunya yang -Liyan (terbentuk oleh sistem patriarki). Kemudian saat fase oedipal ia gagal menjadi manusia berpikiran sepenuhnya, karena tatanan simbolik tidak diciptakan untuk dirinya sepenuhnya. Maka ia menggunakan kerangka pikiran Liyan selamanya.

Inilah yang terjadi pada penulis film dan novel Gone Girl. Sejak awal Gillian Flynn masih berpikir sebagai Liyan. Karena tidak ada di dunia ini yang dapat mengartikulasikan pikiran perempuan sesungguhnya dan sepenuhnya. Perempuan tidak dapat utuh menjadi perempuan. Ini yang menyebabkan Flynn kemudian jatuh dalam penggambaran lama tentang Amy Dunne sebagai seorang perempuan dengan sosok baru di film Hollywood.

\section{Metode}

Objek dalam penelitian ini adalah film Gone Girl. Sumber data yang digunakan adalah data primer yakni film Gone Girl dan data sekunder yakni data yang pendukung yang diperoleh dari sumber tambahan yang berasal dari sumber sumber tertulis seperti buku - buku, artikel, ataupun bahan bacaan dari internet. Teknik pengumpulan data yang digunakan adalah dokumentasi. Dokumentasi adalah cara pengumpulan data dengan melakukan pemaknaan pada pengambilan gambar dan dialog dalam film Gone Girl. Sedangkan metode yang digunakan adalah metode deskriptif.

\section{Hasil dan Pembahasan}

Dalam melakukan analisa film Gone Girl, maka seperti yang telah disebutkan sebelumnya film akan dibagi menjadi tiga bagian: 
1. Bagian pertama: Fokus pada Nick, Amy hanya berupa narasi dari buku harian

2. Bagian kedua: Fokus pada Amy, Nick tetap diceritakan

3. Bagian ketiga: Fokus pada keduanya

Pembagian ini didasarkan pada urutan waktu dan cara penceritaan dalam film. Bagian pertama dan bagian kedua menggambarkan urutan kejadian di hari yang sama yakni tanggal 05, 06, 07, 08 Juli. Tanggal 05 Juli sebagai hari kejadian hilangnya Amy, 06 Juli sebagai hari pertama setelah Amy menghilang, 07 Juli sebagai hari kedua setelah Amy menghilang, 08 Juli sebagai hari ketiga setelah Amy menghilang.

Perbedaannya adalah pada sudut pandang dan situasi penceritaan. Pada bagian pertama fokus pada Nick dengan ditambah narasi buku harian Amy. Pada bagian kedua fokus pada Amy pasca ia meninggalkan rumahnya dan dengan narasi isi hati bahwa semua kejahatan tersebut sebenarnya adalah rencana yang ia buat sendiri. Bagian kedua merupakan twist dari bagian pertama.

Pada bagian ketiga adalah saat mulai tanggal 09 Juli hari keempat setelah Amy menghilang. Fokus penceritaan adalah pada kedua tokoh bergantian. Pada bagian ketiga muncul twist kembali. Pada bagian ini kondisi Nick mulai membaik sedangkan Amy mulai menghadapi masalah. Bagian ketiga juga merupakan bagian terakhir hingga film berakhir.

Dengan membagi menjadi tiga bagian, maka akan memudahkan dalam menggambarkan bagaimana karakter Amy Dunne dikembangkan. Fokus pada penelitian ini adalah pada perkembangan penceritaan tokoh Amy. Bagaimana upaya penulis Gillian Flynn yang ingin mengubah stereotipe tokoh perempuan pada media mainstream namun masih mengalami kegagalan.

\section{Bagian Pertama}

Bagian pertama merupakan bagian yang terpanjang dari film, penggambaran ini dimulai pada 0.00.00 hingga 01.06.09 artinya satu jam lebih dari film digunakan untuk membangun karakter Nick sebagai suami yang buruk dan Amy sebagai korban. Kalimat yang digunakan untuk membangun Amy sebagai korban pertama - tama dengan membuat narasi yang menggambarkan kekerasan pada Nick. Kalimat pembuka tersebut adalah:

When I think of my wife... ...I always think of her head. I picture cracking her lovely skull... Unspooling her brain...

Trying to get answers.

The primal questions of any marriage.

"What are you thinking?"

"How are you feeling?"

"What have we done to each other?"

Kalimat - kalimat tersebut menandakan adanya ketidakberesan di antara keduanya. Munculnya kekerasan cracking her lovely skull, unspooling her brain menggambarkan hasrat menghancurkan dari Nick. Kalimat Trying to get answers menunjukkan adanya ketidakpercayaan pada istrinya. Berdasarkan monolog dari scene pertama tersebut, penonton telah diarahkan untuk tidak menyukai Nick. Nick dibingkai sebagai calon antagonis.

Pada menit ke 03.29 hingga 06.59 digambarkan melalui monolog yang dilakukan Amy Dunne saat menulis di buku hariannya tentang pertama kali ia bertemu dengan Nick. Selanjutnya dalam bagian pertama, tokoh Amy akan digambarkan melalui pengembangan buku harian yang ia tulis.

Amy menggambarkan Nick sebagai a great, sweet, gorgeous, coolass guy. Selama 3 menit lebih, penonton 
diyakinkan bahwa Amy dan Nick pasangan yang saling menemukan. Amy digambarkan sebagai seorang perempuan yang cerdas. Selain itu Amy juga perempuan yang romantis, scene hujan gula putih saat Nick menyentuh bibir Amy sebelum menciumnya merupakan salah satu ingatan kunci bahwa Amy sangat menyukai situasi tersebut. Pengembangan karakter Amy Dunne dapat dibagi menjadi beberapa bagian. Dalam kategori kepribadian, Amy digambarkan dalam kalimat deskripsi beberapa tokoh berikut:

Dialog Nick:

She's a writer

She's a voracious reader

So, she's always got a book in her hand. She was very close with my mom, before she passed away.

She's form New York

She's complicated

She's got very high standards

Amy is my soulmate. She is brilliant.

She's charming, and wise.

Rand Elliot (Ayah Amy):

She's bright, she's beautiful.

She's kind. She really is amazing Amy.

You know, there are millions of people out there Who grew up with her and care about her.

We care about her, we love her.

And we just want her back.

Ibu Amy:

Amy is a decorated scholar.

She forged a successful career in journalism.

She returned here to her husband's hometown...

And she made a life in her adopted home.

Dalam kalimat - kalimat tersebut dapat disimpulkan bahwa Amy adalah tokoh yang cerdas, cantik, senang membaca, penyayang, inspiratif.
Namun di satu sisi Nick menggambarkannya sebagai seorang perempuan New York yang kompleks dan memiliki standar tinggi. Tiga kalimat terakhir Nick mengandung penggambaran yang negatif. Meskipun demikian penggambaran Amy masih tergolong positif. Walaupun Nick telah mengungkapkan sedikit ketidakberesan pada diri Amy. Berdasarkan buku harian Amy maka diperoleh bahwa Amy adalah seorang yang cemburu pada tokoh Amazing Amy. Ia menilai dirinya tidak lebih baik dari tokoh yang terinspirasi darinya. Ini menunjukkan adanya perenggutan identitas dari Amy oleh orangtuanya. Kondisi tersebut tampak dalam dialog berikut:

Buku Harian:

Amazing fucking Amy is getting fucking married

With me, regular, flawed, real Amy, jealous, as always, of the golden child, perfect, brilliant, amazing Amy, who's getting fucking married.

Percakapan Amy dan Nick di pesta pernikahan Amazing Amy:

When I was 10, I quit Cello. In the next book, amazing Amy became a prodigy.

I got cut, freshmen year (Volley ball). She (amazing Amy) made varsity.

She (amazing Amy) got the dog. Puddles made her more relatable.

No, they (Amy's parents) improved upon it (Amy's childhood), and then peddled it to the masses

Amazing Amy has always been one step ahead of me

And then, the night wasn't so bad anymore (Relate to Nick's proposal)

Berdasarkan dialog di atas, Amy menginginkan pernikahan. Ia cemburu pada Amazing Amy yang menikah secara simbolik. Meskipun kemudian Nick melamarnya di malam pesta 
tersebut. Amy digambarkan seperti perempuan yang menginginkan pernikahan. Perempuan yang menginginkan pernikahan merupakan hasil dominasi patriarki. Perempuan yang berusia dan single tidak lebih menarik karena ada ungkapan bahwa ' $a$ women is better dead than unwed'. Sedangkan sebaliknya, pria lajang digambarkan beruntung dan merupakan pria bahagia yang menghindari pernikahan dengan segala konsekuensinya hingga akhirnya suatu saat ia terjebak dalam pernikahan tersebut (Richmond-Abbott, 1992: 193).

Dalam hal ini Amy digambarkan sebagai seorang perempuan tradisional yang menggambarkan banyak perempuan di dunia. Karenanya akan mudah bagi penonton jatuh cinta pada tokoh Amy. Dalam kehidupan pernikahan, Amy digambarkan seorang yang tidak ingin menjadi istri yang tipikal. Amy memiliki impian pernikahan yang ideal dan pemikiran yang modern. Ia ingin menjadi istri yang cool dan keren. Penggambaran pribadi Amy yang tidak seperti rata rata perempuan menikah ini muncul dalam dialog antara Amy dan Nick serta buku harian:

Buku Harian:

Well, it's not true (Marriage hard life). Not for me and Nick.

With us, two years. It's just good.

Dialog Amy:

Promise me we'll never be like them.

All those couples.

Those wives who treat their men like dancing monkeys...

To be trained and paraded.

We're in a recession. If it happens, we'll deal with it.

I'll probably be next.

We have each other.

Everything else is background noise.
Nick: You are exceptional

Dialog Amy:

Nick, I don't get it. I don't get why you're daring me to be someone I don't wanna be.

The nagging shrew. The controlling bitch.

I'm not that person. I'm your wife.

Berdasarkan kalimat - kalimat tersebut, Amy menjadi tokoh yang luar biasa. Ia memiliki pemikiran terbuka dan sikap modern dalam menghadapi pernikahan. Dalam hal ini Amy tidak digambarkan sebagai seorang yang tradisional. Ia menginginkan pernikahan, namun pernikahan dalam konsepnya adalah sesuatu yang berbeda sama sekali dengan pernikahan orang lain. Penggambaran gelap Amy mulai muncul dalam percakapan beberapa tokoh:

Nick \& Rand Elliot:

Rand Elliot :Amy is the kind of girl who attracts admirers.Right, Nick?

Nick Dunne : Yeah, definitely.

Rand Elliot : And we've had instances...where things got..

$$
\text { : scary. }
$$

Margo \& Nick:

Margo : She always attracts...

Nick : Drama? You can say it. It's just me and you

Nick :You want to know the truth? The truth is, Amy didn't want

kids.

I was trying to put a good face on.

Margo : Then suddenly, you've got a pregnant wife.

That's a problem for you.

Especially when you factor in the secret teenage girlfriend

Nick : I didn't tell you that she didn't want kids because she didn't want me to. 
Because it would have just been another reason for you to hate her.

And we had enough of those already! It was easier to just...

Margo : Lie to me?

Nick : I wanted kids!

When we first moved here, I went to a fertility clinic!

Margo : It didn't work?

Nick : I did my part!

When it came time for Amy to do her thing, all of a sudden it was like... No, thanks."

"Well, I don't know. Maybe.

Berdasarkan percakapan tersebut, Amy memiliki daya tarik terhadap lawan jenis yang besar. Kondisi itu membuat pria terobsesi padanya. Amypun cenderung menyebabkan masalah di orang - orang sekitarnya. Dalam percakapan tersebut juga mulai muncul bahwa Amy orang yang manipulatif dan Nick menjadi korban manipulasinya. Berdasarkan buku harian Amy, ia memiliki perasaan kecewa saat kondisi berubah. Ia mengikuti suaminya ke Missouri. Ia tidak keberatan namun merasa sedih harus meninggalkan New York. Nick digambarkan sebagai suami yang kurang peka terhadap kondisi istrinya:

Amy:

So, here's a strange new sentence:

I am a missourian.

No money, no jobs, no prospects.

And then, we heard from go.

So we moved to Missouri, I don't mind.

I just wish he'd asked.

Nick is happy to be home. But I don't know if he's happy I'm with him.

I feel like something he loaded by mistake. Something to be jettisoned, If necessary.

Something dispossable.

I feel like I could disappear.
Kondisi kecewa tersebut semakin memburuk saat Amy merasa diabaikan oleh Nick. Ia merasa dimanfaatkan oleh Nick. Ia merasa menjadi perempuan lain yang ia tidak sukai. Rasa terabaikan itu semakin lama semakin membuatnya takut pada Nick.

Buku Harian:

What scared me wasn't that he'd pushed me.

What scared me was how much he wanted to hurt me more.

What scared me was that I'd finally realized

I am frightened of my own husband

For Valentine's Day, I thought I'd buy a gun.

That is how crazy I've become.

Nick wants me gone but he won't ask for a divorce.

In his mind, I'm the owner of his bar, his only line of credit.

The bitch with the prenup.

I could go home to my parents.

But I'd have to tell them the truth. And I don't even know if I believe the truth.

Can I really think Nick would hurt me?

I'm being paranoid. Crazy.

It's just... I'd sleep better with a gun.

He may truly... Kill me.

Dari bagian pertama Amy dapat disimpulkan sebagai perempuan hampir sempurna, manipulatif dan kompleks yang awalnya optimis pada kehidupan pernikahan namun kemudian mulai menderita karena pernikahannya tidak berjalan lancar. Amy masih digambarkan seperti tipikal seorang heroine pada umumnya dalam sebuah film. Meskipun Amy berbeda dengan heroine biasanya.

\section{Bagian kedua}

Bagian kedua adalah bagian saat twist dimulai. Bagian ini dimulai pada jam ke 01.06.09. Diawali dengan kalimat "I'm 
so much happier now that I'm dead" yang dinarasikan oleh Amy Dunne. Pada bagian kedua, film diceritakan kembali ke hari pertama Amy Dunne menghilang. Kali ini dilihat dari sudut pandang Amy.

Technically missing. Soon to be presumed dead.

Gone.

And my lazy, lying, cheating, oblivious husband...

Will go to prison for my murder.

Nick Dunne took my pride and my dignity...

And my hope and my money.

He took and took from me until I no longer existed.

That's murder.

Let the punishment fit the crime.

Berdasarkan monolog Amy Dunne di awal pembukaan bagian kedua, penonton dapat langsung menyimpulkan bahwa Amy Dunne adalah dalang di balik semuanya. Amy Dunne berubah dari heroine ke villain (penjahat). Ini merupakan aspek yang berbeda dari film lainnya. Seorang perempuan menjadi villain. Gillian Flynn melakukan twist pengembangan karakter. Dari seorang cool girl sweet heart heroine berubah menjadi pelaku kriminal. Sebagai seorang villain, Amy melaksanakan kejahatan dengan seksama. Ia mengatur jebakan kriminal dengan jangka waktu yang cukup lama. Memperhitungkan orang - orang yang akan bersaksi, membuat masalah keuangan, membuat buku harian dan membuat tes kehamilan palsu.

To fake a convincing murder, you have to have discipline.

You befriend a local idiot. Harvest the details of her humdrum life. And cram her with stories about your husband's violent temper.

Secretly create some money troubles. Credit cards, perhaps online gambling.
With the help of the unwitting, bump up your life insurance.

Purchase getaway car. Craigslist. Generic. Cheap. Pay Cash.

You need to package yourself so that people will truly mourn your loss. And America loves pregnant women. As if it's so hard to spread your legs. You know what's hard?

Faking a pregnancy. First, drain your toilet. Invite pregnant idiot into your home...And ply her with lemonade. Steal pregnant idiot's urine.

Voila! A pregnancy is now part of your legal medical record.

Happy anniversary...

Kepribadian Amy yang sebenarnya baru terungkap dalam bagian kedua. Diri Amy yang digambarkan oleh Nick dan keluarganya di bagian pertama adalah diri yang ia buat. Karenanya Amy berusaha menjadi orang yang bukan dirinya. Dari monolog selanjutnya penonton akan menemukan bahwa Amy memiliki banyak lapisan kepribadian. Amy yang sebenarnya menyukai tantangan dan tidak benar - benar hidup dalam kehidupannya sehari - hari. Amy menyukai Nick dan berusaha membuat Nick seperti yang ia inginkan. Amy membentuk Nick agar sesuai dengan keinginannya.

Nick loved a girl I was pretending to be. "Cool girl."

Men always use that as their defining compliment.

"She's a cool girl."

When I met Nick Dunne, I knew he wanted cool girl. And for him, I'll admit, I was willing to try. I waxstripped my pussy raw. I drank canned beer watching Adam Sandler movies. I ate cold piza and remained a size two. I blew him semi-regularly. I lived in the moment. I was fucking game. I can't say I didn't enjoy some of it. Nick teased out 
of me things I didn't know existed. A lightness, a humor, an ease. But I made him smarter. Sharper. I inspired him to rise to my level. I forged the man of my dreams.

We were happy pretending to be other people.

We were the happiest couple we knew. And what's the point of being together if you're not the happiest?

Alasan mengapa Amy membalas dendam pada Nick adalah karena Nick tidak lagi mampu mengikuti ritmenya. Amy merasa Nick pun berusaha menjadi orang yang bukan dirinya. Dan lama kelamaan Nick menyerah. Ia mulai tidak sesuai dengan keinginan Amy. Amy semakin tidak puas saat kemudian Nick berselingkuh.

But Nick got lazy.

He became someone I did not agree to marry. He actually expected me to love him unconditionally. Then he dragged me, penniless, to the navel of this great country...

And found himself if a newer, younger, bouncier...cool girl.

You think I'd let him destroy me and end up happier than ever?

No fucking way. He doesn't get to win.

My cute, charming, salt of the earth, Missouri guy. He needed to learn. Grown ups work for things. Grown ups pay. Grown ups suffer consequences.

Kesimpulan dari monolog tersebut adalah Amy mencintai pasangannya. Yang berbeda dari perempuan pada umumnya adalah Amy senang mempertahankan kepura-puraan. Ia menyukai menjadi orang lain dan mengharapkan Nick mempertahankan hal yang sama. Sebenarnya Gillian Flynn sedang menggambarkan seorang heroine yang klise dengan utopia yang juga klise. Walaupun tidak sepenuhnya.
Sebuah film bergenre drama biasanya mengandung cerita yang berfokus pada perempuan, dengan jalan cerita ideal berupa perkembangan kisah cinta yang lambat dimana tokoh utama perempuan (heroine) dan tokoh lakilaki (hero) jatuh cinta secara bertahap. Deskripsi seksual dibatasi dalam hubungan cinta. Kebahagiaan paling utama adalah saat pertahanan maskulin laki-laki hancur karena cintanya kepada heroine. Terjadi perubahan menjadi pria yang hangat dan menjadi mahluk yang mencintai. Namun demikian, pria tersebut tidaklah lemah, meskipun kekuatan dan kemandirian adalah karakter yang dinilai sedikit lemah. Pria dalam drama haruslah percaya diri dalam kehidupan sosial dan digambarkan sebagai orang yang cerdas, kaya dan berwawasan. Dia maskulin dalam wajah dan perilaku, namun kapasitas kelembutan tersebut biasanya dilukai di awal cerita. Sedangkan heroine dalam cerita harus mandiri dan modern. Bukan seorang yang berkarakter feminin, polos, tidak menyadari kecantikannya dan memiliki pekerjaan yang tidak biasa. Gambaran akan perempuan demikian diindikasi oleh Radway sebagai bentuk fantasi femis yang tersembunyi (Zoonen, 1994:109).

Amy yang disukai Nick (Amy bagian pertama) adalah karakter seorang heroine yang disukai pria. Seperti penjelasan di atas. Heroine dalam cerita harus mandiri dan modern (disukai perempuan). Bukan seorang yang berkarakter feminin, polos, tidak menyadari kecantikannya dan memiliki pekerjaan yang tidak biasa (disukai pria). Amy bagian pertama adalah heroine yang feminin dan polos. Gambaran ini muncul dalam monolog Amy di bagian kedua: 
And if I get everything right, the world will hate Nick...For killing his beautiful, pregnant wife. She was beautiful and smart and kind

Sedangkan Amy yang sebenarnya, merujuk pada pribadinya mandiri dan modern adalah tipikal heroine yang diinginkan perempuan. Sedangkan impian Amy yang mendambakan pria yang cerdas, kaya (berkemampuan finansial) dan berwawasan serta maskulin dalam berperilaku adalah utopia seorang perempuan. Jadi saat Nick tidak dapat memenuhi harapan tersebut, Amy Dunne menjadi tipikal perempuan yang memiliki utopia pada umumnya.

Meski hanyalah tipikal heroine dengan utopia yang klise, yang membedakan tokoh Amy adalah sisi gelapnya yang manipulatif dan upayanya membalas dendam atas kekecewaan yang ia peroleh dalam kehidupan domestiknya. Dalam dunia patriarki, perempuan cenderung mengalah dalam kehidupan rumah tangga. Namun anggapan perempuan seperti ini yang diterobos oleh Gillian Flynn. Ia menggambarkan bahwa jika dikecewakan, perempuan dapat melawan. Inilah kemudian mengapa ia menjadi villain.

Sebagai villain Amy belum sekuat teman - teman villain lainnya. Pada pertengahan film, Amy seorang villain perempuan yang teliti, cerdas dan manipulatif ternyata terkalahkan oleh kekuatan pria. Ia dirampok oleh teman hostelnya. Hal ini sedikit banyak menunjukkan pengaruh nilai patriarki. Bahwa perempuan tetap akan kalah oleh pria. Pria dalam film ini digambarkan bodoh namun sebagai pria ia memiliki kekuatan fisik.

\section{Bagian Ketiga}

Pada bagian ketiga inilah semakin muncul kegagalan Gillian Flynn dalam membentuk sosok perempuan yang baru dan lepas dari penggambaran patriarki. Episode kegagalan ini dimulai saat rencana Amy mulai berantakan karena kejadian yang tidak diinginkan. Uang Amy dicuri oleh teman yang ia temui di hostel tempat ia menginap. Setelah itu Amy sempat kehilangan arah rencana kejahatannya. Hal ini tidak pernah digambarkan dalam film - film lainnya. Seorang villain dalam film pada umumnya selalu memiliki back up plan jika rencana awal gagal. Rencana sempurna Amy digagalkan oleh seorang pria bodoh yang menggunakan kekuatan fisiknya. Kemudian cerita berkembang, Amy mengubah rencananya. Ia memanfaatkan Desi Collings, mantan pacarnya saat SMU yang dituduh menjadi stalker dan mengancamnya. Sejak awal Desi Collings merupakan tokoh yang digambarkan sangat mencintai Amy dan Amy hanya memanfaatkannya saja.

Let me tell you what Amy told me.

She dumped you, you completely unraveled.

You stalked her, you threatened her and you attempted suicide in her bed and were institutionalized.

Amy menemui Desi Collings dan membuat skenario rencana yang baru. Kali ini ia berencana menjadi seorang pelarian. Ia melarikan diri dari suaminya yang kejam. Rencana pemanfaatan Desi Collings inilah yang menjadi salah satu kegagalan Gone Girl dalam menggambarkan sosok villain perempuan yang sempurna dan terlepas dari penggambaran perempuan biasanya. Dengan memanfaatkan rasa cinta Desi Collings, Gillian Flynn membuat Amy menjadi seorang perempuan yang tergantung pada pria. 
Sekilas tampaknya Amy justru memanfaatkan pria, namun sebenarnya muncul makna bahwa rencana Amy tidak akan berhasil tanpa seorang pria dan tanpa memanfaatkan peran - peran feminin.

Peran feminin yang dimanfaatkan adalah rasa tergantung, lemah lembut, membutuhkan perlindungan. Sedangkan dengan memanfaatkan peran feminin tersebut, Amy Dunne sedang menghidupkan kembali apa yang dikenal dengan subtle expectation pada diri Desi Collings. Peran maskulin dapat tercipta kembali jika peran feminin lama diciptakan kembali. Jika peran - peran lama diciptakan kembali maka perempuan akan berada dalam posisi yang dikuasai dan membuat pria memiliki subtle expectation terhadap perempuan (Yusriana, 2014: 130).

Subtle Expectation datang dari bagaimana pria dituntut untuk need to perform saat dating. Yang kemudian melibatkan uang, pria membutuhkan modal untuk pasangannya dan modal tersebut kemudian dikenal dengan resource, pemilik resource menjadi pemilik dominasi dalam hubungan dan tuntutan need to perform sendiri menimbulkan harapan 'tersembunyi' (Subtle Expectation) untuk mengatur si pasangan (Richmond-Abbott, 1992: 156 $-157)$.

Tokoh Amy Dunne memanfaatkan Desi Collings yang memiliki kekuatan keuangan (resource) dan kekuasaan. Amy membutuhkan uang karena ia kehilangan uangnya. Namun dengan diperolehnya resource tersebut, Amy harus memenuhi konsekuensi yang muncul pada diri Desi. Pada diri Desi akan muncul subtle expectation berupa penguasaan akan diri Amy dan cinta Amy.

Di sinilah kemudian tokoh Amy semakin terjebak dalam penggambaran perempuan pada media mainstream.
Amy untuk menyelesaikan rencana tidak dapat terlepas dari tubuhnya. Seperti pada penjelasan sebelumnya pada kajian teori, perempuan selalu dikaitkan dengan seksualitas tubuhnya. Sumber yang dimiliki perempuan tradisional salah satunya adalah daya tarik fisik, ini merupakan daya tarik yang masih dinilai berharga oleh pria. Sedangkan sumber yang dimiliki oleh pria adalah sumber yang dapat digunakan (usable resource) seperti memiliki pendapatan yang lebih besar, memiliki status sosial di luar rumah, kontak sosial dan interaksi di tempat kerja. Dominasi pria dijamin dengan sistem legal serta norma budaya. (Richmond-Abbott, 1992: 187-188).

Daya tarik fisik merupakan daya tarik yang masih dinilai berharga oleh pria. Dibandingkan karier, status sosial dan uang, ternyata sumber daya perempuan yang dinilai lebih oleh pria hanya daya tarik fisiknya, ini kemudian yang menyebabkan pria hanya memikirkan perempuan dari sisi seksual saja (Yusriana, 2014: 155). Subtle expectation Desi tergambar dari scene 01:49:53. Berikut percakapannya:

Desi Collings:

Decent clothes.

Hair dye. Make up. Tweezers.

There's a gym overlooking the lake. The sooner you look like yourself, the sooner you'll feel like yourself.

Kalimat tersebut merujuk pada tampilan fisik Amy. Setelah meninggalkan Nick, Amy mengubah penampilan, warna rambut, gaya berpakaian dan berat badannya bertambah. Berdasarkan monolog sebelumnya:

When I met Nick Dunne, I knew he wanted cool girl. And for him, I'll admit, I was willing to try. I waxstripped my pussy raw. I drank canned beer watching Adam Sandler movies. I ate cold piza and remained a size two. 
Amy yang sebenarnya tidak memperhatikan penampilannya. Amy yang cantik dan sempurna hanyalah Amy yang diinginkan oleh Nick. Karenanya saat Amy melepaskan diri dari Nick, ia tidak lagi memperhatikan penampilan. Untuk mendukung bagaimana Amy yang sebenarnya ditunjukkan beberapa kali kondisi Amy makan makanan ringan. Amy bukan orang yang digambarkan pada bagian pertama. Konsekuensi dari hal tersebut adalah perubahan ukuran tubuh. Berikut adalah urutan perubahan ukuran tubuh Amy:

\section{Gambar 2}

Amy di Bagian Pertama

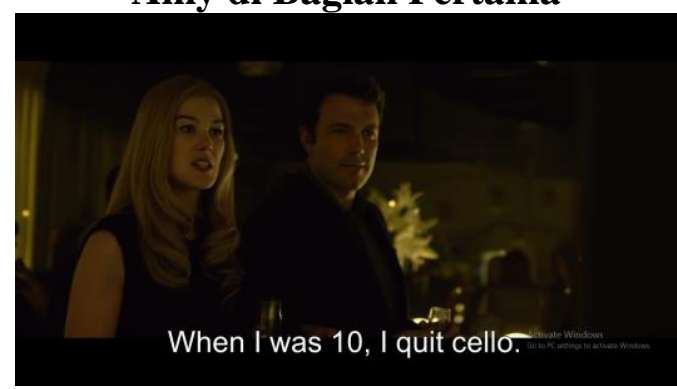

Gambar 3

Amy Menjadi Gemuk di Scene Bagian Kedua

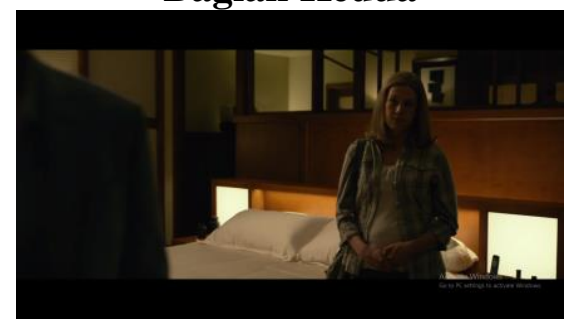

Gambar 8

Amy Kembali ke Ukuran Semula Pada Scene Bagian Ketiga

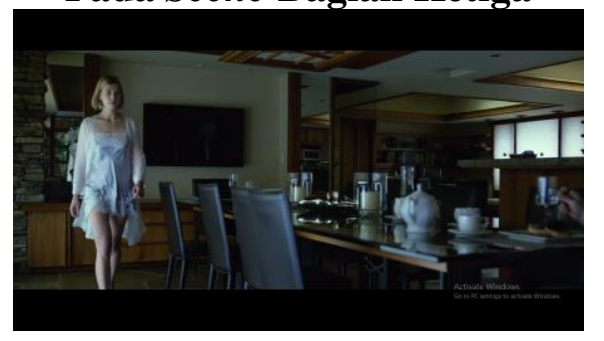

Gambar ketiga, Amy kembali dalam tubuh sempurna dengan pakaian tidur yang terbuka, fungsinya untuk menjaga daya tariknya di mata Desi. Berdasarkan ketiganya maka Amy Dunne memang memanfaatkan tubuhnya untuk keperluannya. Pada bagian pertama, daya tariknya digunakan menarik Nick. Pada bagian ketiga, daya tariknya digunakan untuk memanfaatkan Desi Collings. Kegagalan penggambaran Amy sebagai sosok yang lepas dari peran feminin selama ini adalah saat Amy memutuskan kembali kepada Nick. Hati Amy tergerak saat menonton acara talk show dimana Nick memohon maaf padanya di siaran langsung. Amy yang tergerak ini merupakan bentuk penggambaran perempuan sebagai mahluk emosional. Jika Nick bukan orang yang setia dan tidak sesuai dengan keinginannya lagi, secara logika maka Amy harus meninggalkannya. Namun pada bagian ketiga, Amy mengikuti perasaannya. Berikut monolog Nick di televisi:

I didn't come forward with my affair... Because I knew it would make me look really, really bad.

But I don't care about that anymore. I just want to find my wife.

I'm just trying to get clear...let me be clear.

Just beacuse I am not a murderer doesn't make me a good guy.

I am not a good guy.

I was a bad husband to a great wife.

I broke the vow that I made to her.

It basically means that I was a con artist. I met Amy Elliot seven years ago. I was completely transfixed. Amy can do that to you.

I was this average guy from an average place...

With mediocre aspirations. And I met a woman who dazzled me. And I wanted her to love me... 
So I pretended to be better than I was.

When we got married, I promised to be that guy. That guy who works harder.

That guy who, who lives and acts...

And loves with as much passion as she does.

But I failed her.

Instead of doing what was right. I did what was easy.

She is still alive.

Amy, I love you.

You're the best person I've ever known. And I've taken myself to the woodshed for the way that I've treated you.

And if you come back, I promise...

I will spend every day making it up to you.

I will be the man that I promised you I would be.

I love you.

Come home.

Kalimat - kalimat tersebut yang kemudian membuat Amy memperbaiki rencananya dan berniat kembali pada Nick. Untuk kembali pada Nick mensyaratkan ia membuat skenario baru. Kali ini ia akan memanfaatkan Desi Collings dan membunuhnya. Sekali lagi Amy menggunakan tubuhnya untuk melakukan kejahatan. Tokoh Amy seolah hanya memiliki senjata tubuh untuk dapat melancarkan kejahatannya. Pada scene 02:03:26 hingga 02:05:34 menggambarkan Amy yang memanfaatkan situasi berhubungan intim untuk membunuh Desi.

\section{Kesimpulan}

Dengan menggunakan teori postmodernisme milih Lacan, penulis menjelaskan bahwa Gillian Flynn penulis Gone Girl masih terpaku pada penggambaran perempuan di dunia patriarki. Perempuan masih menjadi seorang Liyan. Hal ini dikarenakan menurut teori ini, bayi mengalami 3 fase dalam pertumbuhannya. Di awal fase, ia mengadaptasi pandangan ibunya yang seorang Liyan dari tatanan simbolik yang ada. Ternyata setelah berada pada fase Oedipal, bayi perempuan yang telah dewasa tidak dapat beranjak dari fase cermin. Kerangka pandangannya terpengaruh ibunya yang Liyan dan tidak dapat lepas sempurna karena tatanan simbolik memang membentuknya sebagai Liyan. Maka perempuan baru inipun adalah Liyan.

Fase tersebut menejelaskan kondisi seorang Gillian Flynn. Sebagai perempuan, ia pun masih seorang Liyan. Karena tidak mungkin ia lepas dari fase cermin sepenuhnya. Pemikiran Gillian Flynn tidak dapat terbebas sepenuhnya sebagai seorang manusia perempuan mandiri. Akibat dari ini adalah kegagalan penggambaran tokoh Amy Dunne dalam film Gone Girl. Gillian Flynn ingin menggambarkan tokoh perempuan yang sama sekali baru. Bahwa perempuan dapat sama jahatnya dengan pria. Namun ternyata, tokoh Amy masih menggunakan penggambaran - penggambaran lama. Penggambaran itu ditunjukkan dengan:

1. Menjadikan Amy seorang heroine dengan utopia yang klise

2. Menjadikan Amy seorang villain yang tidak dapat lepas dari peran peran feminin yang ditanamkan masyarakat, antara lain: lemah (kalah dengan kekuatan fisik pria saat dicuri), mementingkan perasaan dibanding logika (kembali kepada Nick), tergantung pada pria (memanfaatkan Desi Collings) dan menggunakan tubuhnya sebagai senjata (memanfaatkan hingga membunuh Desi Collings). Berdasarkan penggambaran tersebut maka dapat disimpulkan bahwa Gone Girl masih gagal dalam 
menggambarkan sosok perempuan dengan kekuatan baru di media film Hollywood.

\section{Daftar Pustaka}

Kramarae, Cherish. (1991). Women and Men Speaking: Frameworks for Analysis. New York: Newbury House Publishers, Inc.

Richmond-Abbott, Marie. (1992). Masculine \& Feminine: Gender Roles Over The Life Cycle Second Edition. New York: McGraw-Hill.

Tong, Rosemarie Putnam. (2008). Feminist Thought: Pengantar Paling Komprehensif Kepada Aliran Utama Pemikiran Feminis. Jakarta: Jalasutra.

Yusriana, Amida. (2014). Representasi Dominasi Maskulin Dalam Romantic Relationship Analisa Framing Buku Act Like A Lady Think Like A Man. Thesis. Magister Ilmu Komunikasi. Semarang: Universitas Diponegoro.

\section{Sumber Internet:}

Clintock, Pamela. (2014). Box Office: David Fincher's 'Gone Girl' Tops 'Annabelle' With CareerBest \$38M dalam http://www.hollywoodreporter.c om/news/box-office-davidfinchers-gone-738181 diakses tanggal 04 November 2015 pukul 14.05.

Dietz, Jason. (2014). Best of 2014: Film Critic Top Ten Lists dalam http://www.metacritic.com/featu re/film-critic-top-10-lists-bestmovies-of-2014 diakses tanggal
05 November 2015 pukul 13.18 WIB.

Parsi, Novid. (2013). Gillian Flynn on Gone Girl, Interview dalam http://www.timeout.com/chicago /books/gillian-flynn-on-gonegirl-interview diakses tanggal 05 November $2015 \quad$ Pukul 13.12WIB.

Buckley, Cara. (2014). Gone Girl Found: Talking With the Authors of 'Gone Girl' and 'Wild' dalam http://www.nytimes.com/2014/1 1/23/arts/talking-with-theauthors-of-gone-girl-andwild.html?smid=fbnytimes \&smtyp $=$ cur \&bicmp $=$ A D\&bicmlukp $=$ WT.mc_id\&bicm $\mathrm{st}=1409232722000 \&$ bicmet $=14$ $19773522000 \& \_r=1 \quad$ diakses tanggal 05 November 2015 pukul 13.28 WIB.

http://www.boxofficemojo.com/movies/ ?id=gonegirl.htm diakses tanggal 04 November 2015 pukul 13.47

http://www.ranker.com/list/scariestpsychological-thrillers-of-alltime/ranker-film diunduh tanggal 05 November 2015 Pukul 9.14 WIB. 